\title{
The effect of Indigofera Leaf Flour (Indigofera Sp.) with Cocktail Enzymes Treatment in Male Ducks Feed on Growth Performance
}

\author{
Irfan H. Djunaidi, Siti Azizah, Achadiah Rachmawati and Heni Setyo Prayogi \\ Faculty of Animal Science, Brawijaya University \\ Corresponding author: irjuna@ub.ac.id
}

\begin{abstract}
This experimental study aims to evaluate the use of Indigofera leaves that have undergone cocktail enzyme treatment in male Mojosari duck feed. The research treatment was using Indigofera leaves due to enzyme cocktail treatment on male Mojosari duck feed with four levels: 0, 5,10 and 15\% of total feed, with six replications (@ five ducks) using 120 ducks in a completely randomized design. The variables measured and observed in this study were the production performance of male ducks, which included feed consumption, body weight growth, feed conversion. The research results were processed by analysis of variance (ANCOVA) because the coefficient of variation in initial body weight was $17.7 \%$. The results showed that the addition of Indigofera leaf meal to the feed of male Mojosari ducks tended to reduce feed consumption $(\mathrm{P}<0.01)$ and body weight gain $(\mathrm{P}<0.05)$ but did not increase the FCR value $(\mathrm{P}>0.05)$. Indigofera flour needs to be processed first with a cocktail enzyme treatment to improve its nutritional quality so that it can be used as feed for ducks in larger quantities. Male Mojosari ducks that are kept need to be harvested at more than seven weeks to get a higher harvest weight.
\end{abstract}

Keywords. Indigofera, male duck, growth

\section{Introduction}

Indigofera (Indigofera $\mathrm{sp}$ ) is a tree legume that is widely developed as a protein bank, so it is easy to obtain, contains high crude protein (CP) and crude fibre (CF). It has the potential to be used as feed for ducks utilizing plant protein and can digest fiber at high levels. Higher than chicken. High SK levels reduce digestibility in poultry's digestive tract because there are no endogenous enzymes that help digestion so that it passes through the digestive tract of poultry slowly (Garcia et al., 2009). These legumes contain a fairly balanced amino acid and are rich in vitamins, carotenoids, and xanthophylls that give poultry carcasses their yellow colour (Hassen et al., 2007).

The use of Indigofera sp must be within certain limits, that is because Indigofera sp has a high fiber. Tarigan et al. (2010) stated that the dry matter production of Indigofera sp cut at the age of 60 day was 31.2 tons/ha/year. Hassen et al. (2007) stated that the nutritional content of Indigofera sp leaf flour is $89.47 \%$ dry matter, $3788 \mathrm{kcal} / \mathrm{Kg}$ gross energy, $15.13 \%$ crude fiber, $22.30 \%-31.10 \%$ crude protein. Indigofera $\mathrm{sp}$ can also be used as a green concentrate from forage plants or forage mixtures from different species of forage plants. Green concentrates derived from legume-type feed plants also contain chlorophyll and secondary compounds. 
The male Mojosari duck is native to the Mojosari area, Mojokerto district, East Java, with multipurposes. The female sex is a good egg producer, and the male sex is a meat producer with good production performance and egg quality. The use of male ducks as a meat producer would be preferred because of the higher body weight growth and the more tender meat and lower fat content. Production performance and meat quality are also influenced by feed factors, especially protein balance and crude fibre content.

Indigofera leaves, which have a high protein (about 25\%) and a relatively high fiber (about 12\%), are potential feed ingredients for male Mojosari ducks, with cocktail enzyme treatment to remodel fibre improvement quality of the leaves as feed ingredients for ducks. The results of previous studies using Indigofera sp leaves as much as $7.5 \%$ in laying hens showed good results without reducing their production performance (Alfian, Sjofjan and Djunaidi, 2018). The ability of ducks to digest higher fibre will be very prospective to use Indigofera leaves treated with more cocktail enzymes. Enzyme treatment of $0.4 \%$ in apple pulp can increase crude protein and decrease crude fiber (Djunaidi, Nuningtyas, and Muharlin 2020) and can be used up to $15 \%$ in laying quail feed without causing negative effects (Djunaidi, Nuningtyas, and Muharlin, 2021).

Based on this description, it is necessary to research the addition of feed ingredients in Indigofera sp leaf flour, which has been treated with cocktail enzyme treatment to affect the product appearance and meat quality of male Mojosari ducks. The purpose of this study was to evaluate the use of the addition of Indigofera sp leaf flour which had been treated with cocktail enzyme treatment on production performance (feed consumption, body weight growth, and feed conversion).

\section{Materials and methods}

This research was carried out for six months from May to September 2021 at the 'Subur' Animal Husbandry Cage, Buring Kodya Malang sub-district and the Laboratory of Testing and Processing of Livestock Products, Faculty of Animal Science, Universitas Brawijaya. The research materials used were: 192 male Mojosari ducks aged 14 days purchased from Mojosari Mojokerto, 24 plots of floor cage measuring $1 \times 1 \mathrm{~m}$ with cage husk litter, the feed ingredients used in this study were yellow corn, rice bran, concentrate, and Indigofera sp leaf powder was added which was obtained from the Center for Livestock and Forage Development (BPTHMT) East Java. The Indigofera leaves were processed by coarsely grinding (sieving 0.8 ) first with $0.5 \%$ cocktail enzyme treatment. Equipment that supports the research include buckets, scissors, ropes, sample bags, feed containers, drinking containers, Ohaux digital scales with an accuracy of $0.001 \mathrm{~g}$.

\subsection{The Procedure for Making Indigofera sp. Leaf Flour}

The materials used in this study were Indigofera sp leaves harvested at 60 days old. The process of making Indigofera sp. The defoliation age of Indigofera sp is started as a feed ingredient and incubated until the 48th hour so that the enzymes can work. After incubation, then in an oven at $80 \mathrm{oC}$ to stop the enzyme activity, mashed for 60 days by cutting shoots $<0.5 \mathrm{~cm}$ in diameter, then air-dried in a greenhouse for three days, so that the leaves remain green. Furthermore, it is coarsely ground to $0.8 \mathrm{~cm}$ sieving and is ready to be used for $0.5 \%$ cocktail enzyme treatment before being used. Then it becomes DIEC (Indigofera leaves resulting from cocktail enzyme treatment) and is ready to be used as feed ingredients for broiler ducks. DIEC is a research treatment on male Mojosari ducks by mixing the feed with other duck feed ingredients, namely yellow corn, rice bran and duck concentrate, with a composition according to the formulation of the needs of male broiler ducks. Indigofera leaf extraction will be attempted to be carried out simultaneously in quantities according to research needs to uniform the leaf research material.

\subsection{Research Procedures}

Preparation of the cage was carried out seven days before the chick in including a) Cleaning the cage and equipment by spraying disinfectant and liming; b) Installation of curtains/tarpaulins to cover the open side of the cage, c) Installation of 24 cage screens measuring $100 \times 100 \times 60 \mathrm{~cm}$; d) Placement of 
husk litter 3 days before chick in; and d) Installation of lights, brooder and Thermo hygrometer for lighting and maintaining the temperature and humidity of the cage.

The brooding period is from day 1 to 14 . It turns on the brooder non-stop and sets it every 2 hours. The temperature of the cage is according to DOD requirements. The feed was given according to the treatment starting at the age of 15-49 days. Feed and drinking water were provided ad libitum, and the remaining feed was weighed daily. On day four and 28, the ND Lasota vaccine was given through eye drops and drinking water to prevent NCD (new castle disease). Feed consumption and body weight were measured every week to determine the amount of consumption, body weight gain and feed conversion. At the end of the study, the final weight of 120 ducks was weighed, then 24 ducks were randomly selected and slaughtered as samples to calculate the carcass variables and the quality of duck meat. The cutting process is done by cutting three channels: the aortic artery, jugular vein, and oesophagus. then the carcass is cut and separated, weighed to determine the weight of the internal organs

This research method uses an experimental method of feeding treatment with a completely randomized design in the same direction with four treatments and six replications @ eight male ducks. The treatment of this research is the use of Indigofera sp leaf flour processed with a $0.5 \%$ enzyme cocktail (DIEC). The composition of the research treatment feed is as follows: P1: Control feed without the use of DIEC, P2: Treatment feed with the use of 5\% DIEC, P2: Feed Treatment with the use of DIEC $10 \%$, and P2: Feed Treatment with the use of DIEC $15 \%$.

The composition and nutritional content of the treated feed (based on the calculations listed in Table 1.

Table 1. Composition and Nutritional Content of Research Treatment Feed (\%)

\begin{tabular}{lllll}
\hline FEEDSTUFFS & $\mathrm{P} 0$ & $\mathrm{P} 1$ & $\mathrm{P} 2$ & $\mathrm{P} 3$ \\
\hline Yellow corn & 51 & 51 & 51 & 51 \\
Rice bran & 11 & 10 & 9 & 8 \\
Commercial concentrate & 35 & 31 & 27 & 23 \\
Dicalcium Phosphate & 2 & 2 & 2 & 2 \\
Lime & 1,0 & 1,0 & 1,0 & 1,0 \\
Indigofera sp powder & 0 & 5,0 & 10,0 & 15,0 \\
Total & 100 & 100 & 100 & 100 \\
\hline Nutrients content & \multicolumn{5}{l}{} \\
\hline Crude protein \% & 17,26 & 17,22 & 17,51 & 17,72 \\
Crude fat \% & 4,48 & 4,36 & 4,16 & 3,92 \\
Crude fibre \% & 3,40 & 5,66 & 6,96 & 7,85 \\
EM (kcal/kg) & 2.721 & 2.699 & 2.704 & 2.711 \\
Ca \% & 1,25 & 1,50 & 1,51 & 1,51 \\
P \% & 0,67 & 0,67 & 0,67 & 0,68 \\
& P0 = feed control (without Indigofera sp) $;$ P1 $=$ Feed treatment with Indigofera sp 5,0\% \\
P2 = Feed treatment with Indigofera sp $10 \%$ P3 = Feed treatment with Indigofera sp \\
15\%.
\end{tabular}

The variables observed were: the production performance of male Mojosari ducks, including Feed consumption ( $\mathrm{g} / \mathrm{head} / \mathrm{day})$ calculated every week by reducing the amount of feed given to leftover feed, Bodyweight gain (g/head/week): Bodyweight at the end of the week subtracted by body weight at the beginning of the week, and feed conversion (FCR), feed conversion is calculated by dividing the amount of feed consumption by body weight. 


\section{Results and discussion}

The treatment of using Indigofera leaves on male Mojosari ducks gave the same results as control feed (without Indigofera leaves). However, there was a tendency that the use of Indigofera leaves of more than $10 \%$ (P2) would reduce growth performance and feed consumption. Table 2 presents data on the evaluation of Indigofera sp. with Cocktail Enzymes Treatment in duck feed on feed consumption (g/head), PBB (g/head) and FCR Male Mojosari Ducks for five weeks starting at age 15-49 days.

Table 2. Effect of Addition of Indigofera sp. with Cocktail Enzymes Treatment in Feed Against PBB (g/bird), Feed Consumption (g/bird), and Feed Conversion Ratio (FCR) of Male Mojosari Ducks

\begin{tabular}{cccc}
\hline \multirow{2}{*}{ Treatments } & \multicolumn{3}{c}{ Variables } \\
\cline { 2 - 4 } & Feed consumption & Body weight gain & FCR \\
\hline P0 & $646,60 \pm 55,484^{\mathrm{B}}$ & $631,95 \pm 35,018^{\mathrm{b}}$ & $1,026 \pm 0,079$ \\
P1 & $594,17 \pm 14,113^{\mathrm{AB}}$ & $538,11 \pm 42,281^{\mathrm{ab}}$ & $1,110 \pm 0,049$ \\
P2 & $608,31 \pm 45,806^{\mathrm{AB}}$ & $539,05 \pm 45,070^{\mathrm{ab}}$ & $1,141 \pm 0,104$ \\
P3 & $561,63 \pm 38,607^{\mathrm{A}}$ & $492,25 \pm 99,626^{\mathrm{a}}$ & $1,230 \pm 0,062$ \\
\hline
\end{tabular}

Notes: Lowercase superscripts in the same column showed a very significant difference $(\mathrm{P}<0.01)$, and uppercase superscripts in the same column showed significant differences $(\mathrm{P}<0.05)$.

Based on the analysis of variances, the results showed that the addition of Indigofera leaf meal had a very significant effect $(\mathrm{P}<0.01)$ on feed consumption, had a significant effect $(\mathrm{P}<0.05)$ and did not affect the feed conversion value $(\mathrm{P}>0.05)$. It shows that the response of the ducks with the addition of Indigofera leaves in their feed is still tolerant to the level of addition of $10 \%$ in the feed because it still gives the same results as the performance of the ducks from the control feed.

Feed consumption is the amount of feed eaten to meet nutritional needs following the body's needs (Fuller et al., 2004). Feed consumption is calculated by subtracting the feed given with leftover feed. The high and low amount of feed consumption is influenced by feed quality, one of the factors that affect feed consumption is the level of crude fibre in the feed. A high-quality feed with high protein content and low crude fibre will further increase consumption and vice versa.

Indigofera leaf flour added to male Mojosari duck feed will simultaneously provide additional protein and crude fibre so that protein and crude fibre levels will increase. An increase in crude protein level will provide additional protein for ducks. However, this increase in crude fibre will have a negative impact because it will further reduce the digestibility of the feed. The result data showed that the more adding Indigofera leaf meal, the lower the feed consumption so that the protein consumption obtained was also lower. It is mainly influenced by the level of crude fibre in the leaves. The more addition of Indigofera leaf meal, the higher the crude fibre content of the feed, causing a decrease in digestibility, slowing the flow rate of feed, thus affecting the decrease in the amount of feed consumption.

The results of previous studies using Indigofera sp leaves as much as $7.5 \%$ in laying hens showed good results without reducing their production performance (Alfian, Sjofjan and Djunaidi, 2018). Compared to laying hens, ducks can digest higher fibre because they have a larger cache and gizzard capacity, so it is prospective to use Indigofera leaves treated with cocktail enzymes in higher quantities. The results in Table 2 show that adding Indigofera leaf flour to a level of $10 \%$ can still be consumed by Mojosari ducks. Another thing that may affect feed consumption is the anti-nutritional content in Indigofera leaves; in Indigofera, there are anti-nutritional substances. Anti-nutritional substances are found in the leaves and seeds of the Indigofera sp., including tannins and saponins; the rest are alkaloids, flavonoids, carbohydrate glycosides, terpenoids, steroids and indospicine.

Feed consumption which tends to decrease with increasing \% use of Indigofera leaf flour, also causes a decrease in body weight gain. Bodyweight gain (PBB) is the weekly weight gain of ducks obtained by subtracting this week's weight from the previous one. Table 2 shows a significant effect $(\mathrm{P}<0.05)$, namely body weight gain decreased at the use of Indigofera leaf flour. However, statistically, analysis of variation to the level of addition of $10 \%$ still showed the same results, but it was clear that there was 
a decrease in body weight gain. This also caused the final body weight at 49 days to decrease, respectively, 819.8, 725.0, 714.9 and 638.6 grams at P0, P1, P2 and P3. The low final body weight of male Mojosari ducks indicates that Mojosari ducks are genetically more productive than egg-producing birds so that the male sex does not show good body weight gain. The high crude fibre and anti-nutritional levels in Indigofera leaf flour affect the body weight gain of male Mojosari ducks indirectly because previously, it caused a significant decrease in feed consumption.

Male Mojosari ducks with relatively low body weight gain performance can be given up to $10 \%$ Indigofera leaf flour because these ducks can digest fibre better than chickens. Leguminous leaves can be used for feed efficiency efforts with relatively cheap feed prices compared to chickens. Using factory feed and can be used to replace commonly used protein source feed ingredients.

The accumulation of feed consumption and body weight gain of male Mojosari ducks above will affect the feed conversion value. Feed conversion is an indicator for assessing the efficiency of feed use. A high feed conversion value indicates a low feed use efficiency and vice versa. Fuller et al. (2004) stated that feed efficiency (feed conversion) is consumed per unit body weight. One of the factors that affect feed efficiency is the most important is feed energy. Feed efficiency will decrease with age.

The results showed that the use of Indigofera leaf meal in male Mojosari duck feed showed results that were not significantly different $(\mathrm{P}>0.05)$ with control feed, which meant the feed conversion value was the same. This means that there are benefits from this Indigofera leaf as duck feed. The use of Indigofera leaves will reduce feed costs, but the conversion value is the same as without addition.

Factors that affect the level of feed conversion are feed quality, line or offspring and feeding management. Several factors influence feed conversions, such as genetic factors, feed quality (feed conversion is lower if the feed has good quality and feed conversion is higher if feed quality is poor), sex, and cage conditions as ventilation. Good air. Feed quality describes a feed conversion because the value of a feed is determined by feed consumption, body weight gain and feed conversion.

Indigofera sp. is suitable for use as a source of forage both as primary and supplementary feed for protein and energy sources, especially for livestock in high production status. Indigofera has a high protein content, is tolerant of dry seasons, waterlogging, and is resistant to salinity (Hassen et al., 2007). The best nutritional composition in Indigofera leaves harvested at the age of 60 days.

\section{Conclusions and suggestions}

Indigofera leaf meal to male Mojosari duck rearing feed tends to reduce feed consumption and body weight gain but does not increase the FCR value. Indigofera flour needs to be processed first with a cocktail enzyme treatment to improve its nutritional quality so that it can be used as feed for ducks in larger quantities.

\section{References}

[1] García Diñeiro, Y., Valles Suárez, B., Picinelli Lobo, A. (2009). Phenolic and antioxidant composition of by-products from the cider industry: apple pomace. Food Chemistry, 117

[2] Hassen, A., N. F. G. Rethman., Van Niekerk., T. J. Tjelele. 2007. Influence of Season/Year and Species on Chemical Composition and in vitro Digestibility of Five Indigofera Accessions. anime. Science Feeds. Technol. 136:312-322.

[3] Tarigan, A., L. Abdullah, S.P. Ginting, and I.G. Permana. 2010. Production and Nutrient Composition and Digestibility In Vitro Indigofera sp at Different Intervals and Cutting Heights. ITV Journal Vol. 15 No. 3 pp: 188-195.

[4] Alfian A., O. Sjofjan and I. Djunaidi. 2018. Evaluation Of Chlorophyll, Tanin, Gross Energy And The Womb Nutrients On The Leaves And The Seeds Of Indigofera sp. Research J. App. Sci, No. 5 Vol. 77. pp 320-324. DOI https://doi.org/10.18551/rjoas.2018-05.38

[5] Djunaidi, I.H., Y.F. Nuningtyas, and Muharlin 2020. Improving the nutritional content of apple pomace using biological treatments as non-conventional broiler feed. Journal of Animal Science. 30. Vol 2 p. 167-172.

[6] Djunaidi, I.H., Y.F. Nuningtyas, and Muharlin 2021. The Effect of Enzyme Treated Apple 
Pomace as Yellow Corn Substitution on the Carcass Quality, Breast Meat deposition and Percentage of Organs of Broilers. Journal of Animal Science. 31. Vol 2.

[7] Fuller, M. F. (Ed.). (2004). The encyclopedia of farm animal nutrition. Chili.

[8] Akbarillah, T., D. Kaharuddin and Kusisiyah. 2002. Study of Indigofera leaf meal as a feed supplement on egg production and quality. Research Report. Bengkulu University Research Institute, Bengkulu.

[9] Apriana, D.A., I.H. Djunaidi and E.Widodo. 2019. The Effect of Using Mint Leaves (Mentha Piperita L.) in the Form of Flour as Supplementary Feed on the Quality of Broiler Carcasses. Research Report. Brawijaya University

[10] Djunaidi, I.H. and Karimah, N.N. 2019. The Effect of Phytobiotics Giving Sea Bidara Leaf Flour (Ziziphus Mauritiana) in Feed on the Physical Quality of Hybrid Duck Meat. Research Report. Brawijaya University.

[11] Edi, D, N. M. H. Natsir and I.H. Djunaidi, 2020. Profile of laying hens fed with the addition of phytobiotics from teak leaf extract (tectona grandis Linn f.). Journal of Animal Husbandry Vol 17.no 2. 96-102.

[12] Natsir, H. 2014. Production Optimization and Characterization of Biochemical Properties of Glucanase Enzyme from B. Licheniformis Hsa3-1a from Hot Springs, South Sulawesi. 1-9.

[13] Shofa, F.M., E. Soedjarwo and I.H. Djunaidi, 2021. The Effects of Teac Extract Addition (Tectona grandis Linn f.) to Feed on External Egg Quality of Quails. Vol 10. No. 3. 72-75. 